\title{
BAPTIST ETHICS OF CONSCIENTIOUS OBJECTION TO MILITARY SERVICE IN SOUTH AFRICA: THE WATERSHED CASE OF RICHARD STEELE
}

F. Hale ${ }^{1}$

\begin{abstract}
Although the Baptist Union of Southern Africa included relatively few outspoken critics of the apartheid system, during the 1970s and 1980s a small number of its younger members confronted the military system which supported that system of social engineering by refusing to comply with military conscription. Particularly noteworthy among these dissenters was Richard Steele, who had been influenced by the Anabaptist tradition of pacifism in the United States of America. Like his cousin and fellow Baptist, Peter Moll, he countered prevailing sentiments and practices within his denomination by going to prison rather than serve in the South African Defence Force. Steele's action met with little support in the Baptist Union.
\end{abstract}

During the last two decades of the twentieth century international scholarship shed light on the history of conscription and conscientious objection thereto in the Republic of South Africa as that country's apartheid policy and the military apparatus which supported it came under severe critical fire. Such works as Jacklyn Cock's and Laurie Nathan's War and society: The militarisation of South Africa ${ }^{2}$ and the anthology War and resistance: Southern African reports which Gavin Cawthra, Gerald Kraak, and Gerald O'Sullivan edited ${ }^{3}$ thus illuminated previously tenebrous corners of this subject. Others, however, remained in the shadows. Almost completely overlooked in the pertinent scholarly literature, despite the

1 Dr. F. Hale, Department of English, University of Stellenbosch.

2 Jacklyn Cock and Laurie Nathan (eds.), War and society: The militarisation of South Africa (Cape Town and Johannesburg: David Philip, 1989). See also Conscientious objection, $2^{\text {nd }}$ ed. (Cape Town: The Centre for Intergroup Studies, University of Cape Town, 1989).

3 Gavin Cawthra, Gerald Kraak and Gerald O'Sullivan (eds.), War and resistance: Southern African reports (London and Basingstoke: The Macmillan Press Ltd., 1994). 
extensive journalistic coverage it received at the time, is the case of Richard Steele (notwithstanding three sentences in one particularly relevant article ${ }^{4}$ ), which in the early 1980s became an international cause célèbre. In retrospect, it seems particularly noteworthy, because it broke new ground in the treatment afforded South African pacifists and other conscientious objectors to compulsory military service. This was during the last phase of the country's apartheid era, a time when it became increasingly clear to critical observers both in South Africa and abroad that the days of its grand scheme of social engineering along racial lines were drawing to a close. This was also a time when greater numbers of domestic critics of that system were identifying the extensive military apparatus as a chief pillar of apartheid and, accordingly, calling for termination of conscription into it, not least through the End Conscription Campaign.

The Richard Steele case is relevant not only to South African Baptist history but also to the international history of the Anabaptist tradition, even though there is no Mennonite denomination as such in the Republic of South Africa. As will be demonstrated, this universal objector to military service received much of his inspiration from Mennonites in the United States of America during the 1970s and thus served as a personal channel through which their position vis-à-vis militarism was conveyed to South Africa. In the present article we shall inter alia consider why Steele regarded his Baptist nurturing as insufficient for meeting the socio-political crisis in South Africa in which he was intimately involved and, concomitantly, why he found the pacifism of the Mennonite heritage far more relevant. The Steele case will be considered in the context of the history of military conscription and conscientious objection thereto in South African history.

In an episode of South African political history which has received relatively little attention in the pertinent professional literature, the government of the Union of South Africa introduced its Defence Bill, one fruit of the Imperial Defence Conference held in 1911, in parliament early the following year and included in it a clause providing for com-

4 Harald E. Winkler and Laurie Nathan, "Waging peace: church resistance to militarisation", in Cock and Nathan (eds.), War and society: The militarisation of South Africa, p. 328. 
pulsory military service. For approximately the next half-century, however, few South Africans were compelled to perform it. In the meantime, the South African parliament passed the Defence Act of 1957, which would serve as the legal foundation of subsequent conscription. Initially very few men were called up under its terms, which involved a lottery system to select conscripts from a pool which vastly outnumbered the need, owing to the fact that the country was still in a period of relative internal political stability and under no apparent external military threat. That situation changed in the early 1960s, when the massacre at Sharpeville and other incidents of unrest, together with severe police actions and the mobilization of the still small army to quell them, brought South Africa under heavy international criticism. In 1961, in consequence of the tense domestic state of affairs, the period of compulsory service was extended from three to nine months, and 7000 men were drafted into the "Citizen Force". The deterioration of the internal political situation during the 1960s, decolonization and military conflicts elsewhere in southern as well as in central Africa, most notably the origins of the civil war following the "Unilateral Declaration of Independence" in Rhodesia (subsequently Zimbabwe) and armed rebellions against South African hegemony in South West Africa (subsequently Namibia), and South Africa's growing isolation from the international political arena prompted a gradual sharpening of conscription and heightening of the military preparedness of the country. By 1964 the annual intake had risen to ca. 16 500. Pieter W. Botha became minister of defence in 1965, Prime Minister Hendrik F. Verwoerd was assassinated the following year, and in 1967 the government, still in the hands of the National Party, introduced universal conscription for all while male South African citizens and certain resident aliens. As amended that year, the Defence Act did not allow for individual conscientious objection as such; religious objectors were not exempted from military conscription. In this respect, the law lagged behind corresponding statutes in many European and American countries. Nevertheless, members of the few pacifist churches in South Africa, such as the Society of Friends, Jehovah's Witnesses, and Seventh-day Adventists, were allowed to perform non-combatant service in the South African Defence Force but were not given a right to demand this alternative. The discretionary power to assign them to noncombatant units or to perform non-combatant service in combatant 
units resided with registering officers and boards which reviewed cases to determine whether applicants for special status were bona fide adherents of recognised denominations. This system soon proved unacceptable to many such members, especially to Jehovah's Witnesses, whose faith prevented them from performing any kind of military service whatsoever. Their uncompromising noncompliance in an arguably paranoid society with steadily decreasing tolerance of nonconformist behaviour immediately led to an ongoing series of civilian prosecutions for violation of the Defence Act which generally resulted in imprisonment in "Detention Barracks", incarceration often involving severe harassment and both physical and emotional deprivation. ${ }^{5}$ Apart from these churches, there was little explicit opposition to conscription until the 1970s. Then, however, it became a major public issue.

Unleashing the debate was a resolution, unprecedented in South African history, which the South African Council of Churches passed at its annual convention in August 1974. Meeting at Hammanskraal north of Pretoria, delegates at that interdenominational and interracial, though white-dominated, assembly heard General Secretary John Rees call for the dismantling of apartheid. They also considered the question of conscientious objection, an issue which the SACC had taken up at previous meetings. Douglas Bax, a Princeton-educated Presbyterian who was then teaching at an Anglican theological seminary, presented a resolution which he and Beyers Naudé of the Christian Institute had drafted on short notice. This statement, which asked young men who were facing conscription to consider becoming conscientious objectors, prompted a strong reaction at the convention. Some delegates were perturbed at having something that monumental thrust upon them without adequate time to study it properly. After a debate of five hours' duration, however, the resolution passed without a dissenting vote. ${ }^{6}$

5 For a convenient summary of the early history of conscription and resistance thereto in South Africa, see War and conscience in South Africa. The churches and conscientious objection (London: Catholic Institute for International Relations and Pax Christi, 1982), pp. 23-26.

6 David G. Thomas, Councils in the ecumenical movement South Africa, 1905-1975 (Johannesburg: South African Council of Churches, 1979), pp. 87-91. 
Generally speaking, white South Africa rejected the SACC resolution. Particularly strong opposition came from the government; Prime Minister B.J. Vorster issued a thinly veiled threat to take action if the SACC pursued the matter further. ${ }^{7}$ The Afrikaans press, loyal to the National Party and the government, also roundly condemned the resolution, as did leaders of the largest Dutch Reformed Church, the Nederduitse Gereformeerde Kerk. Generally speaking, the English-speaking churches, including the Baptist Union, either opposed the resolution to a greater or lesser extent.

One moderately conservative defender of the status quo, Allen C. Townsend, who edited The South African Baptist, stood in the ranks of those who condemned it. His stance is particularly germane, as it appears to have represented a large segment of white South African Baptist thinking on the issue which would confront Steele not long thereafter. Townsend's opinion of the Hammanskraal Resolution was predictably negative and theologically naïve. He began by seeking to differentiate between the selective objection inherent in the resolution and the position "of the conscientious objector in the generally-accepted sense of the word," which in his perception was evidently that of unconditional pacifism. Townsend acknowledged the venerable Baptist principle of the freedom of the individual Christian's conscience, especially in ethical dilemmas where differing opinions prevailed. Two such matters, he believed, were the injunctions in the Sermon on the Mount to love one's enemies and to return good for evil. This Baptist editor conceded that he was thus compelled to respect practitioners of universal pacifism on New Testament grounds.

We may not agree with his decision, but we must respect it particularly when his obedience is matched by a similar and equally costly obedience in other fields of conduct.

Townsend, in other words, evinced support of prescriptive ethics, at least insofar as it related to literal interpretation of these texts, although he made that respect subjectively contingent on the conduct of the pacifist in other walks of life. But he explicitly ruled out an agapeist interpretation which departed from simple and unconditional obedience to Biblical texts with ethical commands, especially

7 "Premier maan kerke", Die Burger (Cape Town), 3 August 1974, p. 1. 
situation ethics which openly touched on political matters about which he had been defensive for years in the editorial columns of The South African Baptist:

The man who refuses to bear arms on any other grounds than this does not, we believe, fall into the same category as the conscientious objector as defined here. Every other consideration than that of obedience to the commands of Christ as mentioned above, is situational and relative, and therefore secondary.

Townsend nowhere betrayed any comprehension of the complexity of the ethical decision-making process, even for witting or unwitting adherents of prescriptive ethics. That dilemmas constantly arise and commandments can conflict when one seeks to apply prescriptive ethics in daily life he did not seem to grasp. Specifically, Townsend appears not to have understood that there is a deep Biblical basis for condemning social injustice rather than defending it to the death, and that this could clash with such texts as Pauline injunctions to respect the authority of the state in Romans 13 . The intended if inadequately stated crux of the matter, in other words, was lost on this commentator. In fairness to him, it should be stated that in the preamble to their resolution at Hammanskraal Bax and Naudé had neglected to spell out that central point. But, for that matter, Townsend does not even seem to have understood the inescapable centrality of the "just war" theory in any serious debate of this matter in South Africa at that time. On the contrary, he asserted that "the fine distinction between the 'just' and the 'unjust' wars is merely a side-issue." What may have steered much of Townsend's thinking on the matter, however, was fear of the future on a turbulent continent. Like many other ecclesiastical and political opponents of the Hammanskraal Resolution, he adduced a well-worn argument concerning international threats in seeking to undermine the SACC. If we Baptists were to follow the suggestions in its resolution, he averred, then we might just as well

hand ourselves, and all the fellow-members of our Society, to the predators on our borders, regardless of the moral and ethical standards which they profess.

As it did to countless other Christians of that day, it remained axiomatic to Townsend that South Africa, despite what he conceded were disappointing national patterns of conduct with regard to such personal 
matters as marital infidelity and immoderate consumption of alcohol, was still a bastion of Christian civilization. He believed that South Africa needed prophets to call its people back to what he believed were more auspicious times in this respect, but, he professed,

we shall not put the matter right by refusing to cherish and, if need be, to defend, the good which remains to us from our long Christian heritage. ${ }^{8}$

Other Baptists, however, took different positions on the issue. One of them, Scottish-born Alexander Gilfillan, who was then president of the Baptist Union, declared that he would defy proposed legal restrictions on the discussion of the matter. At the 1974 annual assembly of the Baptist Union, he succeeded in convincing delegates to pass a set of six resolutions, one of which affirmed that "genuine conscientious objection" based on Christian principles had "a legitimate place within the Christian tradition and in Baptist conviction" but did not give any means for discerning genuine from false conscientious objection. The fourth, in direct response to suggestions that the proposed statute should forbid counselling objectors, claimed

the right to discuss pacifism freely, and to expound Scripture in support or refutation of pacifism according to one's personal understanding.

The fifth resolution acknowledged and thanked the government for exempting certain categories of conscientious objectors from combatant service but said nothing about the expansion of those categories. The final resolution called upon the government to delete from the proposed Defence Further Amendment Bill Clause 10(c) so as to allow freedom of discussion of conscientious objection. The six resolutions passed by an overwhelming majority. ${ }^{9}$ It must be emphasized that there was no unanimity among South African Baptists on these matters who, generally speaking, continued to look askance at conscientious objection, of which there was no well-entrenched tradition in most of the country's denominations. This, in brief, was the normative stance of the Baptist Union when Steele was about to confront the dilemma of conscription.

8 Allen C. Townsend, "Not in the Same Category!" The South African Baptist, October 1974, pp. 28-29.

$9 \quad$ Ibid. 
Steele was born in Pretoria in 1956. His father was a Scotsman who had emigrated to South Africa shortly after the conclusion of the Second World War; his mother was a native of the country who had long been a member of Central Baptist Church in Pretoria. The Steele family was, by Richard's account, very pious and had devotions every evening after supper. The usual pietistic strictures obtained; tobacco, alcohol, chewing gum, the cinema, card-playing, and riding bicycles on Sundays were forbidden. One dormant seed of Steele's subsequent pacifism may have been sown when his parents decreed that no militaristic toys would be allowed in their home. When on one occasion Richard received a toy firearm for his birthday, his mother immediately confiscated it. The family attended not only his mother's congregation in Pretoria but also Walker Memorial Chapel and Rosebank Union Church in Johannesburg. Like many other Baptist children, Steele sat the Scripture Union's examination on the Bible annually. After four years of primary education in the Transvaal, he was sent to the Baptist Union's boarding school at Treverton near Mooi River in Natal. Steele regarded his years at that institution as highly influential in his spiritual formation and social consciousness, owing partly to a weekly "current affairs session" for the pupils. The principal, Derek Hudson-Reed, moreover, urged them to volunteer to assist at a soup kitchen in a nearby township on Sundays. In what he considers one of his first social ethical decisions, Steele did so when he was in Standards IV and V. On the other hand, the racial dissection of South African society was not challenged at Treverton during his stay at what was then that all-white school. When interviewed in 1991, Steele could not recall ever hearing apartheid criticised there. After five years at Treverton, he returned to the Witwatersrand and spent three years at an English-medium government high school in Kempton Park, where he matriculated in 1974. An outstanding learner and talented athlete, Steele was very active in the Student Christian Association there and also participated in secular extracurricular activities. He was the head prefect of his class, captain of the cricket and athletics teams, and, by his own admission, one of the best students. While serving on the junior city council and as junior deputy mayor he had his first significant contacts with Afrikaans- 
speaking students from other schools, but he did not attribute any particular importance to his interaction with them. ${ }^{10}$

Steele retrospectively believed that his deep involvement in worship and Bible studies at Bonaero Park Baptist Church in Kempton Park as a teenager had not armed him heavily for his subsequent encounter with the South African Defence Force (SADF). Many of the other members of the congregation were post-war British immigrants who laboured at the nearby Atlas factory, which was affiliated with Armscor, the government-held munitions corporation. Steele estimated that 60 per cent of the students in his high school were the children of these and other British immigrants and that "crass racism" prevailed amongst them, many of whom he characterised as "skinheads". He could not recall the pastor at Bonaero Park, George Rae Trew, preaching a single sermon which directly pertained to justice in South African politics or related matters of racism or militarism. This clergyman had reportedly exhorted members of his flock in general terms to turn from their sins but had rarely identified sin and practically never spoken about institutionalized sin in South African society. Like many other white Baptist congregations, however, Trew's church arranged a weekly Sunday afternoon service for black Africans. ${ }^{11}$

Yet Steele also emphasized that his spiritual formation during his years at Bonaero Park had not been entirely irrelevant to his later Christian political activism. Without creating strictly exclusive categories, he characterized Trew's ethical emphasis as being partly on the imitation of Jesus Christ, which complemented his parents' stress on prescriptive ethics and formed part of the background of Steele's conscientious objection. Moreover, another lay member of the Bonaero Park congregation conducted a Sunday afternoon ministry which included worship and soup for alcoholics and other people on the periphery of society in the partly decayed Doornfontein section of Johannesburg. Steele assisted him in this outreach and attributed to his involvement in it a heightened social consciousness. ${ }^{12}$

10 Interview with Richard Steele, Durban, 21 February 1991.

11 Ibid.

12 Ibid. 
Steele also added an international dimension to his social and political awareness while a teenager. At age sixteen he registered for future conscription in accordance with South African law and had no plans to refuse to perform military service. During his final year of high school, a teacher encouraged him to apply for exchange scholarships from both the American Field Service and Rotary International. Steele received one from the latter organisation and spent most of 1975 at a high school in Cortland, New York, a small city near Ithaca. Steele regarded his time there as a "crucial year" in his formation as a Christian and cited two reasons for this. First, it gave him his first opportunity to experience a foreign culture, including a racially integrated high school, and compare it with South Africa. He thereby came increasingly to regard his native society as an "abnormality." Secondly, his host family was "not religious at all", a fact which Steele recalled as "quite a shock for me." Coming from a very pious family, this posed a dilemma for the young exchange student and made his own faith stand out in sharper relief. Steele attended a Baptist church in Cortland but found little social ethical consciousness in it. Nevertheless, during his year in the United States his faith "matured" because he was confronted with the choice of maintaining it or conforming to the secular world of his host family and many of his schoolmates. A close friendship with a devout Roman Catholic boy in Cortland helped him to uphold his spiritual convictions. Steele found that his Christian values gave him an anchoring point in this new milieu, where morals, in his words, seemed "loose, to use an old Baptist phrase." ${ }^{13}$

Steele experienced one incident in Cortland which particularly sensitized him to racial injustice in distant South Africa. State University of New York at Cortland sponsored an Africa focus week, which included a showing of the film "Last Grave at Dimbaza" about a township near East London which served as a dumping ground for people whom the government had forcibly removed from other urban areas. This was a graphic indictment of the homelands system, one which made the initially defensive Steele feel "incensed" at what he perceived as a propagandistic assault on his country. Steele consequently complained to the co-ordinator of the event, insisting that the homelands 
were a "good thing" because they allowed the indigenous peoples of South Africa to develop along their own cultural lines and have their own governments. The American responded that this was precisely what the government of Prime Minister B.J. Vorster had deliberately trained him to believe. This answer made Steele realize that he was "captive" to his white environment in South Africa. ${ }^{14}$

Steele was a changed young man when he returned to his native land early in 1976, but his transformation was far from complete. He still had no qualms about responding obediently to conscription, but the question was not immediately relevant because he followed in the wake of his slightly older cousin and subsequent fellow conscientious objector, Peter Moll, to the University of Cape Town, where he initially intended to study business administration. For unspecified "ethical reasons", however, he shifted his academic course immediately before setting out on his first term and elected instead to study for a Bachelor of Arts with majors in psychology and English and a sub-major in religious studies. It was the last-named subject on which Steele concentrated in 1976 and 1977 . At that time he was very active in the Student Christian Association. Midway through his first year in Cape Town the Soweto riots erupted near Johannesburg, turning the university into a cauldron of political unrest. Together with many of his fellow students, Steele thus attended a political protest meeting on nearby De Waal Drive, the first of many in which he would participate. The entire episode was an agonizing heightening of his critical social conscience which opened his eyes to the profundity of black anger. He was shocked by both black violence in Soweto and elsewhere and the violent response to it by the SADF. In a matter of days the blatantly interracial clash stripped away the tranquil veneer of black and white interaction in the suburban environment in which Steele had grown up. He began to believe that at its most basic level the "the reality of society was hatred, violence, and separation." This represented a Copernican shift in Steele's Weltanschauung, as he had been nurtured on a diet of divine love and principles such as love of one's neighbour, turning the other cheek when assaulted, and seeking to harvest the fruits of the Holy Spirit as described in Galatians. In a period of pro- 
found spiritual Anfechtung, he pondered at length the question of what was the greater reality, New Testament ethical ideals or the hatred and brokenness of South African reality. "Had I been hoodwinked all these years about Christianity?", the young student asked himself. As he sailed through the tempestuous seas of this struggle, the influence of several people on both sides of the Atlantic allowed him to keep his Christian faith afloat. One was the guidance of his more experienced cousin, Peter Moll. Another, amazingly enough in ideological retrospect, was the American Christian Reconstructionist Rousas John Rushdoony, whose understanding of the relationship of Christianity to contemporary society Steele later came to regard as essentially "warped". A third was the support of Bill Houston, a Baptist evangelist in the Student Christian Association. Fourthly, Steele read the works of Martin Luther King, Jr., the renowned African-American Baptist minister civil rights activist and advocate of Christian passive resistance who had been murdered in 1968. Finally, Steele developed a great deal of respect for Michael Lapsley, an Anglican chaplain at the University of Natal who spoke at the University of Cape Town and asked his audience whether there was "room for hope after Soweto." He had answered his own question affirmatively, reminding the Cape Town students that the crucifixion had preceded the resurrection. Buoyed by the witness of these and other Christians in that hour of national crisis, Steele, together with several of his fellow students, founded a Christian social awareness group at the University of Cape Town. One of its first actions came in response to a threatened removal of squatters near Cape Town. Steele went to the site several times to support these people, including one occasion in response to a suggestion made at a meeting at Rondebosch Congregational Church to engage in passive resistance when bulldozers were supposedly rolling towards the squatter camp. Steele went there but nothing happened and no such machines were in sight. He nevertheless later regarded his decision to participate in this kind of resistance as an important one to his ethical development. During the next few years Steele engaged in various other actions of that sort. Whatever relevant training in Christian social ethics he received during this period came from such para-church organisations. Steele worshipped at Claremont Baptist Church during his student days, but the preaching of John Walton, whom he de- 
scribed as a competent Bible teacher, did not touch on contemporary South Africa. Nevertheless, Walton stressed Christian discipleship, so Steele regarded him as "quite valuable" despite the absence of sermons immediately pertinent to the deepening socio-political crisis in the country. ${ }^{15}$

With his essential Christian faith intact and his social consciousness vividly awakened, Steele began to read Christian ethics in the Anabaptist tradition. He also heard the American Mennonite ethicist, John Howard Yoder, speak at an SCA meeting. This theologian's study of imitative ethics, The Politics of Jesus, had appeared in 1972 and quickly gained international recognition. Yoder was the first well-known Christian pacifist whom Steele had encountered, and he was immediately attracted to his social analysis of relations between church and state. At approximately the same time, South African Congregationalist theologian John W. de Gruchy, an increasingly outspoken critic of the Vorster government who was lecturing in the Department of Religious Studies at the University of Cape Town, also began to exercise an influence on Steele's ethical formation, which was evolving in the direction of pacifism. This was at a crucial stage of the latter's life, because he was approaching the end of his three-year period of undergraduate studies and facing the virtual certainty of conscription after receiving his degree in $1978 .{ }^{16}$

By that time some other conscientious objectors had given themselves an alternative to the choice between military service and imprisonment by emigrating from South Africa. Steele never gave that eventuality serious consideration, despite his gratifying experience in the United States. In coming to grips with the dilemma which this posed, Steele consulted many Baptists and other Christians but found no support for his suggestion that he simply resist conscription on the basis of universal pacifism. Repeatedly fellow believers whom he consulted broached the spectre of communism in southern Africa. No-one impugned his motives for considering noncompliance, questioned his sincerity, or directly challenged him on explicitly ethical grounds. Some, however, used the term "foolish" to describe his behaviour and sought 
to influence his thinking by arguing that normal service in the army would give him abundant opportunity to witness to Christ, apparently without considering the possibility that resisting conscription might in itself be a vivid witness. His own pastor countered the suggestion of resistance by appealing to the Pauline injunction in Romans 13 to obey secular authorities. ${ }^{17}$ Steele's parents were "very upset" because disobedience in this case would almost certainly lead to imprisonment, though they respected (but never agreed with) his subsequent decision. Notwithstanding these pressures, the ethics of the imitation of Christ remained dominant in his thinking about the matter. "I continued to ask myself the old Baptist question, 'Would Jesus have done this or that?"', remembered Steele. In his own situation, the specific form of the question became whether Jesus would have co-operated with conscription. To Steele, by then the answer was obviously negative. He had come to regard Jesus as essentially a healer rather than a militant being. ${ }^{18}$

In December 1978 Steele received his baccalaureate degree in English and psychology and briefly returned to the United States, a journey which confirmed his tentative decision to resist conscription and ultimately altered the course of his life. After working in a temporary capacity at a hotel near the Grand Canyon in Arizona, he visited the offices of the Mennonite Central Committee in Akron, Pennsylvania, where, in his words, "it balmed my soul to speak with those nonviolent folks." Steele left Akron with a sheaf of books about pacifism and related topics as well as a list of Mennonite missionaries in southern Africa apart from the Republic of South Africa; revealingly enough, virtually no Mennonites had been able to acquire visas to pursue missionary work in that country. Later in 1979, after returning to his homeland, Steele contacted many of these people. He also returned briefly to his alma mater to acquire a higher education diploma in order to be qualified as a high school teacher. ${ }^{19}$

17 For an analytical survey of how South African Baptists have tended to employ this locus classicus to justify uncritical acceptance of governmental authority, see Frederick Hale, "Romans 13:1-7 in South African Baptist Social Ethics," South African Baptist Journal of Theology, I, no. 1 (1992), pp. 66-83.

18 Ibid.

19 Ibid. 
Steele's second stint at the University of Cape Town brought him yet another step along the road to resistance. He became involved in a Quaker alternative service project which Professor Paul Hare, an American sociologist then temporarily at that institution, had initiated. A small group of Quakers had bought a van which they converted into an ambulance and begun to convey children from squatter camps to a pediatric clinic at a hospital. Steele served in this endeavour once a week. From the fertile soil of this project sprouted the plan to drive an unofficial ambulance to a war zone in northern Namibia and, in collaboration with a missionary hospital, spend two months treating people in need of medical care as a graphic example of what conscientious objectors could accomplish if given such an opportunity instead of being incarcerated. Both military and civil authorities initially approved the project, but when the ambulance reached the operational area security forces halted it and escorted it back to Windhoek. They then interrogated, held in custody for a night, and deported from Namibia Steele and his fellows as "undesirable" in December 1979. Despite the failure of the project to reach maturity, Steele later regarded it as significant to his own development, because it gave him an opportunity to put his ethical insights into practice. ${ }^{20}$

In the meantime Steele had written and sent to several people in the SADF a nine-paged, double-spaced letter explaining the basis of his conscientious objection and stating categorically that despite receiving an order to appear for induction into the army he would "not report for duty on 4 July 1979, and will treat any future call-up for military service in the same manner". This statement, essentially a rejection of violence on the grounds of Christian conviction, is one of the most revealing Baptist documents in the struggle against conscription in South Africa and therefore merits fairly detailed consideration.

Steele began his case by stating that he was a Christian, specifically a Baptist, and declaring that "Christ is at the centre of my life, and so he acts as a reference point for all that I do, think or say." This keynote pointed in the direction of imitative ethics, although Steele's meta-ethics could not be entirely characterised as such. Intimately

20 Interview with Richard Steele, Durban, 27 February 1991. 
related to the imitation of Christ in his understanding of ethics was the supremacy of agape and concomitant total rejection of violence:

I believe violence is the antithesis of love, and love as taught and practised by Jesus Christ is at the very centre of the Christian way of life.

Violence in all its forms, he reasoned, was not only inherently unchristian, but indeed itself sinful, "because it arises out of man's alienation from God and from his fellow man." Steele linked this to Old Testament anthropology by spelling out in conventional fashion the fall of Adam and Eve as the fountainhead of this alienation from the divine, the murder of Abel as the first instance of resulting interpersonal violence, and God's consequent punishing of the human race beginning with the flood. There was little in this with which most other Christians would have disagreed. Steele's use of the New Testament was appropriately selective and emphasized both Gospel and Pauline texts which corresponded to his understanding of the imitation of Christ as the essence of Christian discipleship and of Christian agape as the source of healing and life. Among these were Ephesians 5:1-2 ("Therefore be imitators of God, as beloved children. And walk in love, as Christ loved us and gave himself up for us, a fragrant offering and sacrifice to God."), the Lord's Prayer and its epilogue in Matthew 6:14-15 ("For if you forgive men their trespasses, your heavenly Father also will forgive you; but if you do not forgive men their trespasses, neither will your Father forgive your trespasses."), and John 13:34-35 ("A new commandment I give to you, that you love one another; even as I have loved you, that you also love one another. By this all men will know that you are my disciples, if you have love for one another."). Building on these and several related prescriptions and precepts as his New Testament foundation, Steele proceeded to spell out his understanding of Christian discipleship as peacemaking, the core of which he found in active, imitative love as referred to in Matthew 5:9 ("Blessed are the peacemakers, for they shall be called sons of God."). "Love is the lubrication in the peacemaking process", he declared, without, however, defining love.

A peacemaker is not a detached observer of violence and hostility, but plunges right in and actively seeks to bring about peace and reconciliation in that situation. In whatever situation he finds himself, he actively works for peace. 
Postulated in this line of reasoning was the assumption that one could fulfil the commandments of Christ. Steele's beliefs thus bordered on Christian perfectionism. Be that as it may, in his conviction that peacemaking lay at the core of discipleship, Steele believed he had found his true calling:

I want to be a peacemaker here in South Africa. I want to be used by God in the process of reconciliation between the peoples of our land so that we may live together in true peace - a peace undergirded by justice and righteousness.

He could not do so by becoming a soldier, for that would mean dispensing with Christian injunctions to turn away from the sin of violence and indeed casting overboard his entire understanding of Christian ethics:

I am striving to cultivate a non-violent lifestyle: non-violence is the refusal, ever, to leave out of consideration the affirmation of the dignity of the other person, because he bears the image of God (Gen $1: 27 ; 9: 6)$. In situations of conflict, non-violence does not seek to defeat or humiliate the opponent, but to win his friendship and understanding. The end is not the destruction of the opponent, but his redemption.

Steele sought to obviate objections to his generalisations on the wellworn grounds that South Africa's conflicts were different and justified on the grounds that they were defensive or ultimately promoted a larger good:

I do not believe that there can ever be such a thing as a Just War because violence cannot ever be justified: one can never get round the theological fact that violence is contrary to the command to love, no matter in what context it is used - whether to maintain the status quo or to overthrow it.

If Steele was aware of conventional "Christian realist" responses to what some critics might dismiss as the naïveté of his argumentation, the counter-argument that the exercise of healing might at times necessitate the use of force to protect life from relentless aggression, he gave no indication of such awareness in his statement.

Steele knew of nothing more antithetical to this understanding of Christian love and its apposition to violence than militarism. Without initially mentioning the SADF, he made his theological dis- 
course immediately relevant to the case at hand by declaring in general terms that

violence and war dehumanize. War is only possible in as much as men become things. Military training, as preparation for war, conditions the whole man — physically, psychologically and spiritually - to become an efficient mechanism of death.

Steele then related this macrocosm to the microcosm of his own land and, within it, his own status:

As I see it, the South African Defence Force is caught up in the spiral of violence, as is any country's defence force. I do not wish to join the Defence Force because I do not wish to participate in that violence. In this respect I could be classified as a universal pacifist because I would refuse to do military service in any country anywhere in the world under any circumstances. ${ }^{21}$

Steele's letter apparently threw a spanner into the works of conscription. Less than a fortnight later he received a telegram from the SADF informing him that his call-up had been postponed until $1980 .{ }^{22}$ As 1979 drew to its close, however, Steele realized that his hour of conscription was imminent. Believing that it would be most prudent to take again an activist approach to the matter rather than being entirely passive, he arranged interviews with four people in the SADF, namely Chaplain-General J. A. van Zyl, the prominent Baptist chaplain Andrew van den Aardweg, the registering officer who would assign him to national service, and the legal officer of the unit that he knew would call him up. Steele had two purposes in making these interviews. First, he regarded it as a matter of courtesy and tact to contact the men in question personally; secondly, he wanted to express as clearly as he could his willingness to perform alternative service outside the SADF. The interviews took place at the end of 1979 and very early in 1980 but failed to accomplish anything. Steele found Van Zyl to be "extremely hostile". The chaplain-general showed him a Christmas message he had recently contributed to the military magazine Paratus in which he had declared categorically that no conscientious objector or pacifist could with a clear conscience kneel before the crib of Jesus, and informed him

21 Richard Steele Private Archives, uncatalogued materials, Richard Steele (Cape Town) to various recipients in the SADF, 11 June 1979.

22 Ibid.; handwritten memorandum by Richard Steele at conclusion of copy of letter. 
that the SADF distributed Bibles and other Christian literature in Angola, an action which the young resister thought "contradictory" in the light of what he believed was its utterly unchristian military activities there. (In an appendix to this confrontation, one which Steele aptly characterised as a "remarkable story", he visited Van Zyl after completing his subsequent period of incarceration in detention barracks. To his pleasant surprise the chaplain-general greeted him warmly this time, thanked him for coming, and informed him that in the interim he had become an advocate of conscientious objection.) The registering officer was no less antagonistic and reportedly told Steele that "conscientious objectors should be made to walk through mine fields or simply put up against a brick wall and shot." ${ }^{23}$

Steele received orders to report for induction in late January 1980. Following a classic pacifist practice, he informed the legal officer in writing that he did not intend to obey this command. His initial confrontation with his unit was a bizarre illustration of the SADF's inability to deal competently with conscientious objectors. Steele's parents transported him to its headquarters near Johannesburg. He entered the building and repeated his intention not to serve. The legal officer who was to deal with this case of noncompliance was out playing sport, however, so another officer sent Steele to the military police. Upon arrival at their office, they declared that since they did not have proper documentation pertaining to him he was free to go home for the night. Steele thus took a commuter train to a point approximately two kilometres from his parents' house and walked the remaining distance. "It felt like coming home from the dead," he recalled several years later. "It was like visiting from another planet." The following day Steele was transferred to the regional headquarters of the SADF in Pretoria but again was told to go home temporarily. This time his father, who was employed in Johannesburg, collected him. Steele thus remained a free man, though one awaiting prosecution for refusing conscription, for another three weeks. ${ }^{24}$ 
His chances of escaping unscathed from a trial must have seemed remote, because only a few weeks earlier a military court had found his cousin, Peter Moll, guilty of a similar offence and imposed a sentence of eighteen months' incarceration in detention barracks. That incident had gained a great deal of publicity in South Africa and left the law challenged but unchanged. Steele's own trial took place before a military tribunal during the fourth week of February 1980. He was charged with failure to report for military service without having a good reason for not complying with that order. Steele pleaded not guilty on the grounds that he indeed had a good reason. He told the court that he regarded the SADF as a pillar of a fundamentally unjust society. "It is common knowledge that thousands of young men fail to report for their military service each year and that some flee the country," he argued, adding that in contrast to those who emigrated he desired to remain in South Africa and "serve my country as a peacemaker." Steele emphasized that he was not a totally recalcitrant resister seeking merely to avoid personal hardship:

I am prepared to work in circumstances similar to those of the national servicemen, in the operational area, if necessary for a longer period and for less pay. But I cannot subject myself to military authority or wear a uniform.

The only witness called was Steele's pastor in Kempton Park, George Rae Trew, who testified to his character and informed the court that while Baptists in general were not conscientious objectors, the denominational tradition laid great weight on the principle of individual choice in matters of conscience and therefore Steele was being faithful to his Baptist heritage. Privately, Trew told Steele that he still disagreed with his grounds for refusing to perform military service. In the end, all argumentation was to no avail. The tribunal found Steele guilty and sentenced him to eighteen months' imprisonment in the detention barracks at Voortrekkerhoogte. Six months of the sentence were suspended. It was declared that if, after completion of the initial term, Steele again refused to perform military service, a recurring sentence of two years might be imposed. The tribunal rejected a request by the defence counsel to allow Steele to investigate the possibility of performing rehabilitative alternative ser- 
vice in the Prisons Department, where he could apply his education in psychology, rather than merely being a prisoner himself. ${ }^{25}$

Steele's life in detention barracks became itself a testimony to his principles, though not one without a considerable amount of emotional and physical hardship more severe than anything else he had experienced. He entered the facility at Voortrekkerhoogte, where he had visited Moll a few weeks earlier, entirely certain that he was being obedient in Christian discipleship and therefore confident that God would maintain him through the ordeal. Yet Steele was conscious of the peril which he faced, because he was aware that two years earlier two prisoners there had been ordered to march without respite until they died of exhaustion. At the time of his own entrance, he believed that he was crossing a crucial border and found some freedom in this conviction. He was, by his own retrospective account, prepared to die for it. ${ }^{26}$

Steele sought to uphold his principles from the first day of his incarceration. Officially regarded as a soldier and thus ordered to wear a uniform, he refused to do so. A supervising officer consequently ordered him to be locked up in an ordinary cell. The following morning a man whom Steele later recalled as "the chief bully" approached him at breakfast and ordered him to wear an overalls uniform. Again, not knowing what that man's disciplinary function was in the detention barracks was, he intrepidly refused to co-operate. Later that day he was court-martialled for this noncompliance to a regulation and sentenced to solitary confinement. Steele's third supposed infraction was to refuse to shave his beard. On this occasion he successfully defended himself on the basis of the detention barracks' own rules, however, which he knew permitted prisoners who had beards upon arrival to retain them, though not to initiate beards in captivity. Steele consequently boasted a beard throughout his imprisonment, a defiant symbol of his nonconformity. This victory did not herald many others. On the contrary, Steele was repeatedly sentenced to solitary confinement for refusing to march and salute officers, addressing officers as "Mister", 1980, p. 3.

26 Interview with Richard Steele, Durban, 27 February 1991. 
and generally refusing to execute orders but only doing tasks which he was asked in a "civil way" to do. He consciously tried to nurture cordial relations with the people around him, behaving as though he were in the civilian world and engaging in civilian conversation. In all of this Steele and Moll sought to give each other moral support. That, of course, was impossible during most of the time when either or both of them were in the block of six solitary confinement cells. Even when confined there, however, the two cousins were occasionally allowed to exercise together. Yet many hours Steele passed in stultifying boredom. The only reading material he was permitted to have in solitary confinement was the Bible. He refused to accept the version which the SADF offered him, preferring instead to use his more complete study version of the Jerusalem Bible. ${ }^{27}$

In May 1980, some four months after his arrival at Voortrekkerhoogte, the SADF transferred Steele to a military prison in Bloemfontein. He believed the purpose of this move was to separate him from Moll, because their combined persistence in refusing to comply with military regulations was influencing other prisoners. Steele estimated that 99 per cent of those men, most of whom were being punished because they had taken absence without leave or otherwise disobeyed regulations, regarded him and his cousin as heroes because of their disobedience. At Bloemfontein, Steele's behaviour again led to long periods of solitary confinement and, as a result, great mental stress. He sought to counter its effects by writing large numbers of letters. The resulting publicity began to yield results. Amnesty International adopted him as a prisoner of conscience. Helen Suzman, a fiery critic of the Botha government and one of the few members of the Progressive Federal Party who sat in parliament during the early 1980s, brought up his case in that chamber. Letters of support reached Steele in increasing numbers; during 1980 he received over 2000 of them. Steele's own efforts also prompted some degree of official response. He asked to be examined by a clinical psychologist and to have onehour visits by members of his family every month. These requests were granted. In mid-1980, moreover, the SADF appointed a commission of inquiry into his and Moll's cases. The board of inquiry included Van 
Zyl, the head of the army, the surgeon-general, and the chief legal officer of the SADF. Sailing what it may have regarded as a pragmatic course, on 11 August the commission recommended that the two young Baptists no longer be given orders which they were likely to refuse to obey and that in contrast to most other military prisoners they be accommodated with Jehovah's Witnesses for the remainder of their sentences. To Steele this was an important victory, one which represented de facto recognition of their status as conscientious objectors, not merely "disobedient soldiers" or criminals who selfishly shirked their duty to perform military service, even though they did not belong to a recognised "peace church". Some opponents of conscientious objection later regretted making this concession. Brigadier C.J. Pretorius, a legal officer, declared in 1981 that it had been a "fatal error" because it set a precedent which would be awkward to respect and which led at least one other detainee to demand similar treatment that year. Major M.C. Krige, who commanded the detention barracks at Voortrekkerhoogte, declared in 1981 that no further concessions would be made to conscientious objectors. ${ }^{28}$ But Steele and Moll were free men. Thanks to the victory they had won, the former spent the rest of 1980 living with Jehovah's Witnesses, wearing simple blue overalls without military insignia and working in his choice of prison occupation, namely gardening. Military chaplains visited him during this period, though the Baptist ones were not amongst them, a fact which the disappointed Steele did not forget. While he had been at Voortrekkerhoogte, only one, a Presbyterian named James Grey, seemed sympathetic. A Roman Catholic chaplain who called on him once in Bloemfontein complained to his superiors about the conditions under which Steele was being held but, perhaps owing to pressure from above, did not return. He also remembers the fact that his own pastor, George Rae Trew, visited him only once, even though while he was at Voortrekkerhoogte more frequent calls could have been feasible. In Bloemfontein Steele's closest spiritual ally was a Dutch Reformed SADF hospital chaplain in the permanent force named Willie van Rooyen who eventually left the military establishment. Despite these exceptions, Steele found it impossible to respect SADF chaplains; he

28 "Move on military objectors an error, court told", Rand Daily Mail, 8 August 1981, p. 2. 
perceived them as essentially obliged to the military hierarchy, beneficiaries of its salaries and perquisites, and otherwise beholden to worldly authority. Most seriously, however, Steele reacted negatively to their practice of rationalizing warfare and military service to the soldiers to whom they ministered. He believed this was "the most distressing aspect" of their status. ${ }^{29}$

Even after his transfer to Bloemfontein, Steele sought to nurture the development of his Christian faith and to witness to the people around him. His vegetarianism afforded one opportunity to do the latter, despite - or perhaps owing to - the practical difficulty of maintaining his dietary principles while in prison. Steele's persistent refusal to eat meat, he believed, convinced some of the people around him of the sincerity of his conscientious objection. Steele read the entire Old and New Testament and for a while conducted a Bible study for his fellow inmates, an activity which did not have the approval of the military authorities but one which they presumably would have found awkward to halt. In connection with this Steele recalled doing a lot of reflecting on Biblical texts while confined and gaining many insights into them, owing to the stark contrasts between New Testament ethical ideals and the conditions he was experiencing. He became particularly close to those fellow prisoners who were Jehovah's Witnesses and, notwithstanding the gap between his university education and the modest schooling which most of them had, benefited from "very valuable interaction" with them. Detention barracks became a venue for a lay ministry in other ways, as well. Steele later recalled that he carried on loving and caring for people, not least by counselling them, and therefore did not regard his period of incarceration as a waste of time. ${ }^{30}$

Steele's ethics continued to evolve during this period, largely because of his extensive reading. He perused works by Mohandas K. Gandhi and was immediately impressed by the Mahatma's integration of spiritual values, especially his reverence for life, and their practical application. The young Baptist, disillusioned by some of the bitter fruits of the sectarian ethics he had experienced in South African Christian circles, also found that the universalism of Gandhi's approach to 
religion struck a chord in him. In harmony with this, an Anglican liturgical work to which he had access gave him insight into the ancient notion of the "communion of the saints" and prompted him to appreciate more fully the spiritual presence of fellow believers and feel an affinity with them despite the physical distance from nearly all of them. This further nurtured a broadening personal spirit of religious toleration which continued to evolve within him long after his liberation. He became increasingly convinced that the divine was not confined to people of any one denomination, creed, or religion. By contrast, the militant passages of the Hebrew scriptures "disgusted and shocked" Steele, and he found the triumphalism of Judaism and Christianity, particularly as manifested in his own Baptist tradition, "too petty". ${ }^{31}$

Given this further unfolding of his spirituality and ethical position, it would have been virtually impossible for Steele to resume active membership in a typical South African Baptist congregation after his release, and in fact he subsequently rarely darkened the door of a Baptist chapel. He stated without rancor or immodesty in 1991 that he had grown beyond his denominational tradition, which he perceived as implicitly "rather hostile" to him and that it had become evident that the Baptist Union simply had not satisfied his needs when he was trying to take very seriously the implications of being a Christian in a fundamentally unjust and violent society. Steele's activities after his release in 1981 amply illustrated the direction which his spiritual pilgrimage has taken him. In 1981 and 1982 he spent several months in Europe and South America. The International Fellowship of Reconciliation, a broadly based, inter-religious pacifist organisation founded in 1914 and headquartered in the Netherlands, arranged a lecture tour for him in the United States of America and Canada. Steele then spent the 1982-1983 academic year in Elkhart, Indiana, as an irregular student at Associated Mennonite Biblical Seminaries. In August 1984 he began to serve as the caretaker of the Gandhi Centre near Durban, an institution which was destroyed in interracial violence the following year. Steele and his wife, Anita Kromberg, were detained for two weeks in 1985 because of their involvement in anti-conscription activities. 
A year later the International Fellowship of Reconciliation gave him a post in Durban involving inter alia assisting foreign visitors interested in gaining insight into race relations in South Africa. Until the early 1990s he was still active in the movement to end military conscription. Steele's religious involvement for many years beginning in the late 1980s was primarily in a Quaker meeting, where he found the absence of ordained clergymen, the emphasis on the direct personal experiencing of the divine, general doctrinal latitudinarianism, silent worship (as opposed to what he in an uncharacteristically severe indictment generalised is "the pseudo-intellectual sermonising" of most Christian denominations), and rejection of violence amenable. ${ }^{32}$

While in many instances direct historical causation can be fiendishly difficult to demonstrate, it seems highly likely that the publicity surrounding the Steele case, together with that of Peter Moll, made an impact on both general white opinion in South Africa and, more specifically, that of the Baptist Union. To be sure, no precise quantification is possible, but there can be little doubt that in the 1980s conscientious objection gained considerably more acceptance in that denomination than had been the case during the previous decade. There were, of course, other factors at work, not least the seemingly endless and wearying struggle against the independence movement in Namibia which cost many young South Africans their lives.

In 1980 the Christian Citizenship Committee of the Baptist Union reported that it had spent "a considerable amount of time" on the matter and found the provisions of the existing law "inadequate since they deny recognition of the individual conscience which is recognised in Scripture". ${ }^{33}$ Theodore Pass, who had been a conscientious objector in the United Kingdom during the Second World War and subsequently emigrated to South Africa, and other denominational leaders subsequently called on State President P.W. Botha to present the case for statutory amendment. Andrew van den Aardweg, a high-ranking Baptist chaplain in the SADF, reportedly informed the CCC that its representations to the State President were instrumental in bringing about the eventual change to the consideration of cases on an individual as

32 Ibid.

33 The South African Baptist Handbook for 1980-1981 (n.p., n.publ., n.d.), p. 95. 
opposed to a denominational basis, because Botha would not have listened to similar arguments from, for example, Roman Catholics or Anglicans. The Baptist Union had not antagonised the government through severe criticism, as had the leaders of certain more outspoken denominations, especially those which were still affiliated with the SACC. ${ }^{34}$ Throughout the remainder of the 1980s the CCC continued to press for greater flexibility in the definition and treatment of conscientious objectors. Eventually the entire issue of conscription dissipated when in the 1990s the "new South Africa" adopted the principle of all-voluntary military establishment. In this episode of history, as in many others, the Anabaptist legacy played a subtle and indirect but nevertheless contributory part in bringing about change.

Keywords

Christian Ethics

Conscientious Objection

Richard Steele
Trefwoorde

Christelike Etiek

Gewetensbeswaar

Richard Steele

34 Interview with Theodore D. Pass, Johannesburg, 26 March 1991. 